\title{
EFFECT OF COLD STORAGE AND DIFFERENT PACKAGING MATERIALS ON THE QUALITY OF FRESH ROSEMARY HERB: I- EFFECTS ON MARKETING VISUAL QUALITY AND SHELF-LIFE Abdel-Kader, H.H.; Kh.H. EL-Hindi.; Hekmat Y. Massoud and Fatma K. Badawy \\ Veget. and Flor. Dept., Fac. Agric., Mansoura Univ.
}

\begin{abstract}
Fresh culinary herbs are one of the fastest growing markets for gourmet production on a world wide scale. Some herbs are sold fresh rather than dry because they do not retain their flavor when dried. Rosemary (Rosmarinus officinalis, L.) plant is an important aromatic culinary herb.

A study was carried out during two successive summer seasons 2006 and 2007, at the Post Harvest Lab in the Veget. and Flor. Dept., Fac. of Agric., Monsoura Univ. Fresh rosemary herbs were packaged in nine different packaging materials: Butter bags (P1), Cellophane bags (P2), Nylon bags (P3), Polyethylene bags (P4), Aluminum foils (P5), Aluminum plates covered with foil (P6), Aluminum plates covered with plastic film (P7), Foam plates covered with foil (P8), Foam plates covered with plastic film (P9). The packages were stored at (room atmosphere, 1,3 , and $5^{\circ} \mathrm{C}$ ) for 6 weeks.

This study was conducted to study the effect of cold storage and different packaging materials on the quality of rosemary fresh herb.

This part (I): aimed to investigate the effect of cold storage temperatures and different packaging materials on the marketing visual quality and shelf life of fresh rosemary herb.

The results showed that increasing storage period resulted in increasing of the fresh weight loss and decreasing the total chlorophyll content. While, the shortest storage period of the herb, the less the changes in their fresh weight, and the slowest the chlorophyll degradation.

Herbs kept in Butter bags (P1) lost their fresh weight faster and sharper than those kept in other packaging materials, while those in Aluminum foils (P5) were the least to lose weight and had steadier pattern than the other packaging materials. Herbs kept in Butter bags (P1) and Foam plates covered with plastic film (P9) had lower chlorophyll content than other packages.

At the end of the storage period (after six weeks), herbs kept in Aluminum foils (P5) and Aluminum plates covered with foil (P6) had the least fresh weight loss percentage, and the highest chlorophyll content in both seasons. It is also clear that Aluminum foils (P5) and Aluminum plates covered with foil (P6) kept the chlorophyll content of the herb at high values for long period especially at $1^{\circ} \mathrm{C}$.

The shelf life of the three storage temperatures varied slightly among each other's but significantly with room temperature, with favor to the lower cold temperature. The worst package was Butter bags (P1) in both summer seasons. Aluminum foils (P5), Aluminum plates covered with foil (P6), and Foam plates covered with foil (P8) had longer shelf life than other packaging materials.

Summing up all factors, herbs in Aluminum foils (P5) and Aluminum plates covered with foil (P6) stored at $3^{\circ} \mathrm{C}$ maintained their fresh weight, chlorophyll content, and achieved longer shelf-life than other treatments in both seasons.
\end{abstract}




\section{INTRODUCTION}

Herbs are used for food supplements, cooking, medicines, cosmetics, aromatherapy, and many other products. Fresh culinary herbs are one of the fastest growing markets for gourmet production on a world wide scale, (Kowalchik et al., 1998). Some herbs do not retain their flavor when dried and must be used fresh. These fresh culinary herbs are; basil, sage, chives, oregano, dill, marjoram, mint, parsley, rosemary and thyme, (Cantwell, 1996).

Rosemary (Rosmarinus officinalis L.) is one of many nature herbs that to be stored because it increase applicants in last period. Rosemary plant is an evergreen shrub of the mint family Lamiaceae (also known as rosa maria) was famous "for strengthening the memory" as long as 2,000 years ago, (Keville, 1999).

Fresh culinary herbs are variable in botanical origin and in their post harvest properties. The best post harvest conditions for preservation of fresh rosemary herb include storage at low temperature with using different packing materials, (Cantwell and Reid, 1993). Under this condition, a shelf life of 6 weeks can be expected, (Rogers and Fischetti, 1994).

Temperature is the most important factor in maintaining quality after harvest. The optimum post harvest temperature for fresh thyme, oregano, rosemary, mints, sage, parsley, cilantro, savory, marjoram, dill, and tarragon is $0 \stackrel{\circ}{\circ}$. Under controlled conditions, a shelf life from 3 to 4 weeks can be achieved at this temperature. Most herbs, storage at $0{ }^{\circ} \mathrm{C}$ with $>95 \% \mathrm{RH}$ is required to optimize quality and storage life. Expected shelf life is 3 weeks at $0^{\circ} \mathrm{C}$ and 2 weeks at $5{ }^{\circ} \mathrm{C}$, (Cantwell, 1996).

Moisture loss is the second most important post harvest factor affecting the quality and shelf life of herbs. Most herbs respond favorably with very high humidity $(>95 \%)$. Water loss can severely degrade quality, and the relative humidity inside the storage unit directly influences water loss of the product, (Wilson et al., 1995). Lowering the holding temperature to the recommended levels also greatly reduces water loss. The herbs keep better at low temperatures close as possible to $0^{\circ} \mathrm{C}$. The relative humidly in the packing area, cold rooms, and transport vehicles should be maintained at a high level (>95\%), (Joyce and Reid, 1986).

Herbs can be packaged in bags designed to minimize water loss and store refrigerated, (Bhide, 2006). When herbs are packaged this way, it is particularly important to maintain constant temperatures, to reduce

condensation inside the bag and the consequent risk of fungal or bacterial growth. The bags may be partially ventilated with perforations, or may be constructed of a polymer that is partially permeable to water vapor, (Cantwell, 1992). Most fresh herbs of the Labiate's family keep well when packed in cartons lined with folded perforated polyethylene (PE), in which water loss, leaf abscission and decay are minimal, (Aharoni et al., 1993). The salad mix contained the leafy herbs was stored at 0,5 , or $10 \stackrel{\circ}{\circ} \mathrm{C}$ for 14 days in perforated or non perforated polypropylene bags, (Tomkins and Channell, 2000).

Quality characteristics are largely visual and include appearance of freshness, uniformity of size, form and color, lack of defects (damaged or 
yellowed leaves, decay, insect damage, wilting). Characteristic aroma is essential for culinary herb quality, (Cantwell, 1996). Kmiecik et al. (2001) found that the content of chlorophyll in dill was reduced by $17-30 \%$ after 14 days of storage in the cold room at $1{ }^{\circ} \mathrm{C}$. The chlorophyll content of packaged herbs was best maintained at the lower storage temperatures between 3 and $10{ }^{\circ} \mathrm{C}$, and yellowing of the packaged herbs was affected by the storage temperature, (Sankat et al., 1996). Freshly harvested spearmint herbs stored at 0 and $5{ }^{\circ} \mathrm{C}$, and sweet basil stored at 5 and $10{ }^{\circ} \mathrm{C}$ also retained high chlorophyll "a and b" contents, (Al-Kershi, 2003).

This research aimed to study the effects of different cold storage temperatures along with different packaging materials on the storage ability and marketing visual quality (expressed as changes in the fresh weight and chlorophyll content) and shelf- life of fresh rosemary herbs.

\section{MATERIALS AND METHODS}

The present study was carried out at the Post harvest lab in the Veget. and Flor. Dept., Fac. Agric Monsoura Univ. during two successive summer seasons (2006) and (2007). Plant samples of Rosemarinus officinals L., (rosemary) were taken from mother plants grown in the Medicinal and Aromatic Plants Farm, Fac. Agric Monsoura Univ. Rosemary plants were harvested on the first week of July in both summer seasons. Early in the morning and before harvesting, plants were gently washed in the field with a water hose to remove the field dust off the plants. Two hours later, plants were harvested by cutting the herb $10 \mathrm{~cm}$ above soil surface without bruising or injuring the leaves and stems. The cut herbs were carried to the lab and placed on tissue paper for one hour to cool down and fanning before storage. Fresh herb samples (50g each) were weighed and packaged in nine different packaging materials:
1- Butter bags (P1).
2- Cellophane bags (P2).

4- Polyethylene bags (P4).

3- Nylon bags (P3)

6- Aluminum plates covered with foil (P6)

7- Aluminum plates covered with plastic film (P7)

8- Foam plates covered with foil (P8)

9- Foam plates covered with plastic film (P9)

The first four treatment (P1, P2, P3, and P4), bags were perforated to airing. The different packages were divided into four groups; the first group was left in the lab at room atmosphere, while the other three groups were placed inside refrigerators and stored at three different temperatures $(1,3$ and $5{ }^{\circ} \mathrm{C}$ ). The samples were examined every week until the end of the shelf life of the herb. During storage periods, weight of herbs and chlorophyll content were measured weekly for comparison with control samples that stored at room atmosphere. 
Abdel-Kader, H.H. et al.

Data recorded:

1-Initial fresh weight of the samples was set as $50 \mathrm{~g}$ for each replicate.

2- Weight loss (\%): Every week, five plant samples were randomly taken from each packaging material under each storage temperature (total 20 samples for each package), weighed and the percentage of their weight loss was calculated as the percentage of the difference between the initial weight and the recorded ones at the date of sampling.

3- Total chlorophyll content (mg / $100 \mathrm{~g} \mathrm{FW):} \mathrm{Every} \mathrm{week,} \mathrm{five} \mathrm{plant}$ samples were randomly taken from each packaging material under each storage temperature their chlorophyll was calorimetrically measured as described by Herbert et al. (1971), and the total chlorophyll content was determined mg chlorophyll / $100 \mathrm{~g}$ herb FW.

4- Shelf-life (weeks): Every week, five plant samples were randomly taken from each packaging materials under each storage temperature and their shelf-life was measured with number of weeks for marketable herbs after each storage period. Shelf-life was terminated when the herbs lost more than $20 \%$ of their initial fresh weight, lost appearance of freshness and color, or showed some defects such as yellow leaves, decay, or growth of fungus.

Experimental design

The experimental design was factorial experiment in complete randomized blocks design with three replicates, each replicate contained twenty packages. All the plants stored inside nine different storage materials at four storage temperatures (room, 1,3 and $5^{\circ} \mathrm{C}$ ) for 6 weeks storage periods.

\section{Statistical analysis:}

Data of the present study were statistically analyzed and the differences between the means of the treatments were considered significant when they were more than least significant differences (L.S.D) at the levels of $5 \%$ according to Gomez and Gomez (1984).

\section{RESULTS AND DISCUSSION}

\section{Effect of cold storage and packaging materials and their interactions on fresh weight loss (\%) of rosemary herb:}

Figure (1) clearly shows that herbs kept at room atmosphere lost their fresh weights faster and sharper than those stored in the refrigerators that lost their fresh weights at almost the same pattern until the end of the third week. However, those stored at $1^{\circ} \mathrm{C}$ showed slightly less changes in their fresh weight than those stored at $3^{\circ} \mathrm{C}$ or $5^{\circ} \mathrm{C}$ after the third week and until the end of the sixth week of storage. Similarly, Al-Kershi (2003) reported that freshly harvested spearmint and sweet basil in higher temperature $\left(20{ }^{\circ} \mathrm{C}\right)$ had higher weight loss than those stored at $0 \stackrel{\circ}{\circ} \mathrm{C}$ or $5{ }^{\circ} \mathrm{C}$. The effect of low temperature could be attributed to its effect in reducing water loss from the herb as mentioned by Joyce and Reid (1986) who reported that lowering the holding temperature to the recommended levels greatly reduces water loss. 
J. Agric. Sci. Mansoura Univ., 34 (12), December, 2009

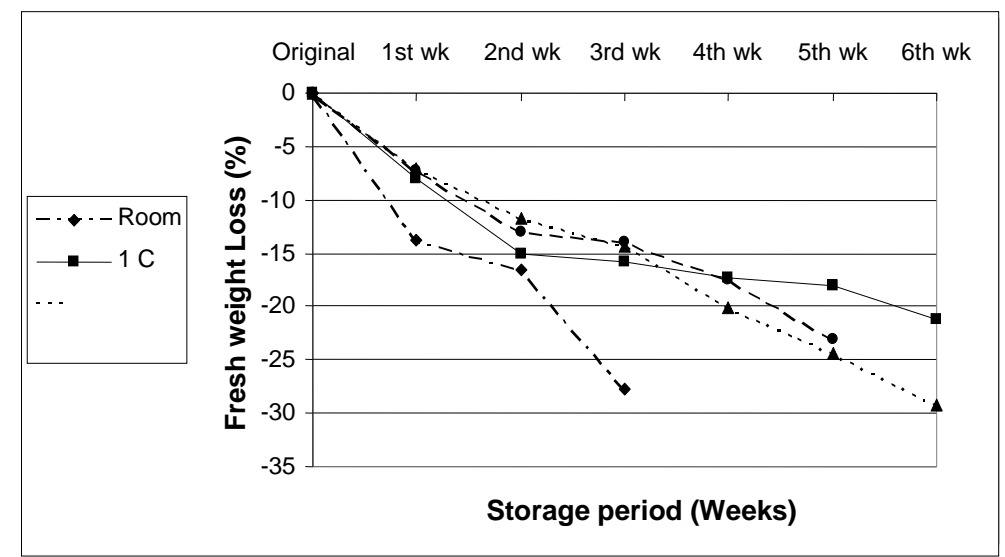

Figure (1): Fresh weight loss (\%) of rosemary fresh herbs stored at room temperature, 1,3 and $5^{\circ} \mathrm{C}$ throughout 6 weeks storage period (Mean of both summer seasons 2006 and 2007).

Figure (2) clearly shows that herbs in all packages continued to lose their fresh weight with increasing the length of storage period. The figure shows that packing materials lost their fresh weights at different patterns. Herbs kept in Butter bags (P1) lost their fresh weight faster and sharper than those kept in other packaging materials, while those in Aluminum foils (P5) were the least to lose weight and in a steadier pattern than the other herbs.

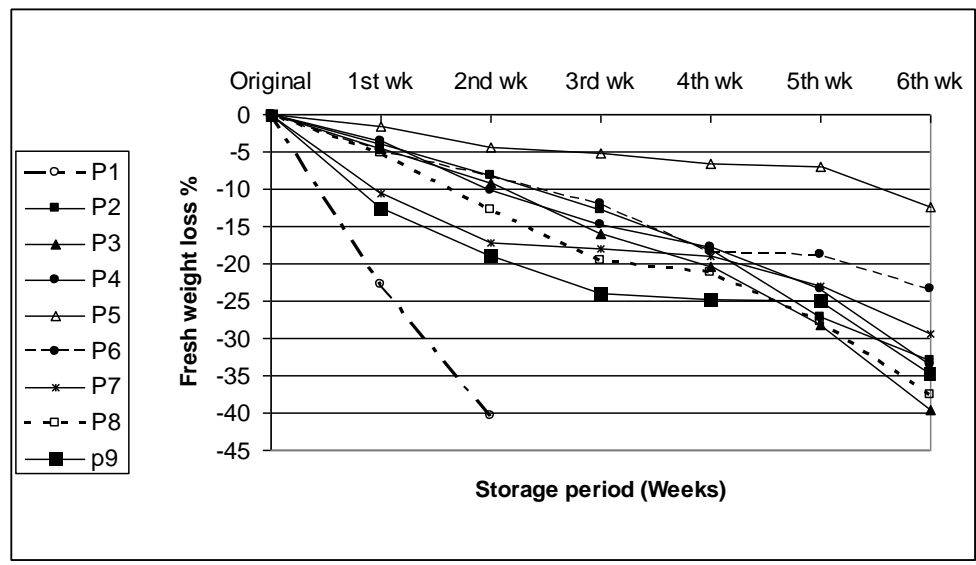

Figure (2): Fresh weight loss (\%) of rosemary herbs stored in different packaging materials* throughout their 6 weeks storage period (Mean of both summer seasons 2006 and 2007).

* Butter bags (P1)

Nylon bags (P3)

Cellophane bags (P2)

Aluminum foils (P5)

Aluminum plates covered with foil(P6)

Aluminum plates covered with plastic film (P7)

Foam plates covered with foil (P8)

Foam plates covered with plastic film (P9) 
Abdel-Kader, H.H. et al.

Herbs in the other seven packages were intermediate between the two formerly mentioned packages (P1 \& P5), but herbs kept in Aluminum plates covered with plastic film (P7) and Foam plates covered with plastic film (P9) showed sharper and more weight loss after two weeks of storage than those packaged in Cellophane bags (P2), Nylon bags (P3), Polyethylene bags (P4), Aluminum plates covered with foil (P6), Foam plates covered with foil (P8). It worth to mention here, that P7 and P9 packages were both covered with plastic film. Different types of packaging material would have different permeability and gas exchange ability. In the same concern, Kwon-HyeJeong et al. (1998), studied the effects of packing in antifogging film (AF), polyethylene (PE) or wrap film on celery, and reported that fresh weight losses were more influenced by type of film used.

The data in Table (1) shows the interactions of the studied factors on the weight loss percentage of rosemary fresh herb during the two seasons. Data shows that all used packaging materials showed a significant reduction in their fresh weights during the two experimental seasons.

The highest significant weight loss percentage was $(40.78,34.87,24.59$ and $26.12 \%$ ) at room temperature, 1,3 and $5{ }^{\circ} \mathrm{C}$ respectively in the first season and $(40.44,30.80,27.03$ and $26.62 \%)$ in the second season in the same order by using butter bags (P1). The lowest fresh weight loss \% was $(8.60$, $8.40,3.00$ and $1.69 \%$ ) at room temperature, 1,3 and $5{ }^{\circ} \mathrm{C}$ respectively in the first season and $(8.43,7.86,4.72$ and $2.52 \%)$ in the same order in the second season by using Aluminum foils (P5).

Increasing the storage period resulted in increasing of weight loss percentage, as may be attribute to excess in water loss by long storage. Similar results were obtained by Yamauchi and Watada (1993) on parsley and Gomez et al. (1999) on coriander.

The least fresh weight loss percentage of rosemary herb resulted from Aluminum foils and Aluminum plates covered with foil during the different storage periods in both seasons. Butter bags packaging material gave the highest fresh weight loss percentage at the various cooling temperatures $\left(1,3\right.$ and $\left.5^{\circ} \mathrm{C}\right)$ through the storage period in the two seasons. Whereas, the other different packaging materials gave intermediate values of weight loss reached the significance level in the most cases.

These results are in accordance with those of Karwowska (1997) on basil and tarragon, Kwon-HyeJeong et al. (1998) on celery, Gomez et al. (1999) on coriander, and Al-Kershi (2003) on spearmint and sweet basil who obtained similar results. This result may be in part due to the environmental conditions (temperature, light and relative humidity) where the herb grew, that reflected on the physiological and biochemical processes in the herb under storage conditions. 
Table (1): Fresh weight loss (\%) of rosemary fresh herb as affected by different packing materials and storage temperature (room, 1,3 and $5{ }^{\circ} \mathrm{C}$ ) and their interactions during 6 weeks period in the first and second summer seasons (2006 \& 2007).

\begin{tabular}{|c|c|c|c|c|c|c|c|c|c|c|c|c|c|}
\hline \multirow{3}{*}{$\begin{array}{l}\text { Packaging } \\
\text { materials }\end{array}$} & \multirow{3}{*}{$\begin{array}{c}\text { Storage } \\
\text { Temp. } \\
{ }^{\circ} \mathrm{C}\end{array}$} & \multicolumn{12}{|c|}{$\begin{array}{l}\text { Storage periods (weeks) } \\
\end{array}$} \\
\hline & & \multicolumn{6}{|c|}{$1^{\text {st }}$ season } & \multicolumn{6}{|c|}{$2^{\text {nd }}$ season } \\
\hline & & 1 & 2 & 3 & 4 & 5 & 6 & 1 & 2 & 3 & 4 & 5 & 6 \\
\hline \multirow{4}{*}{$\begin{array}{l}\text { Butter bags } \\
\text { (P1) }\end{array}$} & Control & 31.09 & 50.46 & - & 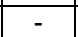 & . & - & 29.31 & 51.56 & - & - & - & - \\
\hline & 1 & 25.29 & 44.46 & - & - & - & - & 22.29 & 39.31 & - & - & - & - \\
\hline & 3 & 18.08 & 35.30 & - & & - & - & 20.36 & 33.69 & - & & - & - \\
\hline & 5 & 16.93 & 31.09 & ( & - & - & - & 19.78 & 33.46 & 䅦 & & - & - \\
\hline \multirow{4}{*}{$\begin{array}{l}\text { Cellophane } \\
\text { bags } \\
\text { (P2) }\end{array}$} & Control & 6.44 & 14.73 & 18.04 & - & - & - & 4.96 & 9.74 & 18.91 & it & - & - \\
\hline & 1 & 3.55 & 6.47 & 10.34 & 14.90 & 20.53 & 329.17 & 3.06 & 7.84 & \multicolumn{3}{|c|}{11.7815 .3219 .44} & $\begin{array}{l}422.59 \\
4\end{array}$ \\
\hline & 3 & 3.50 & 8.43 & 15.52 & 26.91 & 32.12 & 236.81 & 9.12 & 14.15 & \multicolumn{3}{|c|}{519.9127 .0633 .53} & \begin{tabular}{|l|l|}
3 & 37.48 \\
\end{tabular} \\
\hline & 5 & 2.33 & 3.40 & 7.06 & 13.00 & \begin{tabular}{|l|} 
\\
\end{tabular} & - & 3.55 & 6.16 & \multicolumn{3}{|c|}{10.1014 .7419 .30} & - \\
\hline \multirow{4}{*}{$\begin{array}{l}\text { Nylon bags } \\
\text { (P3) }\end{array}$} & Control & 3.64 & 11.27 & 19.02 & 29.01 & - & - & 19.87 & 26.30 & 27.73 & \begin{tabular}{|l|}
$3-$ \\
-
\end{tabular} & - & - \\
\hline & \begin{tabular}{|l|}
1 \\
\end{tabular} & 5.92 & 10.17 & 16.39 & 20.16 & 27.10 & 040.16 & 7.43 & 10.66 & \multicolumn{3}{|c|}{13.4117 .5321 .21} & \begin{tabular}{l|l}
1 & 31.05
\end{tabular} \\
\hline & 3 & 3.18 & 8.28 & 13.78 & 25.28 & 35.06 & 639.00 & 5.58 & 9.91 & \multicolumn{3}{|c|}{14.1825 .6330 .96} & 35.87 \\
\hline & 5 & 5.38 & 9.47 & 14.49 & 16.91 & 22.32 & & 8.08 & 11.64 & \multicolumn{3}{|c|}{13.3515 .1416 .80} & - \\
\hline \multirow{4}{*}{$\begin{array}{l}\text { Polyethylene } \\
\text { bags } \\
\text { (P4) }\end{array}$} & Control & 6.29 & 13.98 & 18.10 & \begin{tabular}{|l|}
- \\
\end{tabular} & - & - & 7.55 & 15.58 & 21.50 & - & - & - \\
\hline & 1 & 3.74 & 7.61 & 12.14 & 16.32 & 24.46 & 629.83 & \begin{tabular}{|l|l}
3 & 4.91
\end{tabular} & 13.53 & \multicolumn{3}{|c|}{\begin{tabular}{|l|l|l|l|l|} 
& 17.51 .36 & 30.17
\end{tabular}} & \begin{tabular}{l|l}
77 & 39.84
\end{tabular} \\
\hline & 3 & 3.78 & 15.92 & 23.31 & 28.98 & 32.01 & 137.33 & 7.21 & 12.27 & \multicolumn{3}{|c|}{21.5830 .1536 .29} & \begin{tabular}{l|l}
9 & 40.72 \\
\end{tabular} \\
\hline & 5 & 0.75 & 3.62 & 6.02 & 8.29 & 13.83 & \begin{tabular}{|l|l|}
3 & - \\
\end{tabular} & 2.56 & 3.97 & \multicolumn{3}{|c|}{\begin{tabular}{|l|l|l|}
7.06 & 8.73 & 13.76 \\
\end{tabular}} & $6-$ \\
\hline \multirow{4}{*}{$\begin{array}{l}\text { Aluminum } \\
\text { foils } \\
\text { (P5) }\end{array}$} & Control & 3.63 & 10.90 & 15.75 & \begin{tabular}{|l|}
- \\
\end{tabular} & - & - & 3.07 & 10.90 & 11.26 & \begin{tabular}{|c|}
$5-$ \\
5
\end{tabular} & - & - \\
\hline & 1 & 1.90 & 4.15 & 6.77 & 9.92 & 13.29 & $\begin{array}{l}918.75 \\
\end{array}$ & 2.11 & 5.31 & \multicolumn{3}{|c|}{\begin{tabular}{|l|l|l|}
7.68 & 10.9015 .28 \\
\end{tabular}} & \begin{tabular}{l|l|}
8 & 22.15 \\
\end{tabular} \\
\hline & 3 & 0.35 & 1.14 & 2.42 & 3.43 & 4.53 & 6.13 & 0.27 & 1.19 & 2.01 & 2.84 & 3.74 & 5.04 \\
\hline & 5 & 0.17 & 0.90 & 1.66 & 2.32 & 3.39 & & 0.18 & $\mid 0.92$ & \multicolumn{3}{|c|}{\begin{tabular}{|l|l|}
2.02 & 2.73 \\
\end{tabular}} & 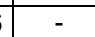 \\
\hline \multirow{4}{*}{$\begin{array}{c}\text { Aluminum } \\
\text { plates } \\
\text { covered } \\
\text { with foil } \\
\text { (P6) }\end{array}$} & Control & 3.47 & 8.99 & 13.35 & - & 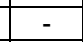 & & 3.50 & 8.39 & 12.37 & $7-$ & - & \\
\hline & 1 & 2.31 & 4.76 & \begin{tabular}{|l|}
6.87 \\
\end{tabular} & 9.05 & 12.01 & 115.38 & 1.98 & \begin{tabular}{|l|}
4.57 \\
\end{tabular} & \begin{tabular}{|l|}
6.59 \\
\end{tabular} & 9.02 & 12.20 & 16.22 \\
\hline & 3 & 1.74 & 4.91 & 11.24 & 15.76 & 12.78 & 821.33 & 0.86 & 1.82 & 4.27 & 5.90 & 7.00 & 8.45 \\
\hline & 5 & 11.35 & 14.11 & 10.40 & $|<0.21|$ & 139.45 & - & $10 .<0$ & 13.69 & 10.54 & $+<0.04$ & 1.04 & - \\
\hline Aluminum & Control & 9.25 & 34.24 & 46.47 & - & - & - & 23.32 & 39.03 & 50.71 & - & - & - \\
\hline & \begin{tabular}{|l|}
1 \\
\end{tabular} & 12.00 & 23.46 & 34.11 & 44.88 & \begin{tabular}{|l|l|} 
& - \\
\end{tabular} & - & 11.64 & 20.51 & 32.97 & 43.27 & - & - \\
\hline ed with & 3 & 4.80 & 9.19 & 14.54 & 20.08 & 26.10 & 37.65 & 5.68 & 8.60 & 14.51 & 19.49 & 924.17 & $\begin{array}{ll}7 & 35.23 \\
\end{array}$ \\
\hline (P7) & 5 & 5.98 & 12.90 & 20.05 & 23.26 & 28.02 & - & 7.48 & 14.82 & 18.80 & 23.67 & $\mid<5.14$ & \\
\hline Foam p & Control & 9.95 & 23.82 & 35.48 & - & - & - & 9.35 & 29.52 & 38.98 & \begin{tabular}{|l|}
$3-$ \\
\end{tabular} & - & - \\
\hline & 1 & 2.83 & 7.23 & 12.88 & 17.36 & 26.73 & 333.18 & 3.73 & 10.35 & 15.86 & 21.32 & 228.63 & \begin{tabular}{l|l|}
3 & 37.54 \\
\end{tabular} \\
\hline & 3 & 7.23 & 11.06 & 14.67 & 19.96 & 29.41 & 136.13 & $\begin{array}{l}3.71 \\
\end{array}$ & 10.89 & 15.15 & 18.02 & 222.67 & \begin{tabular}{l|l}
77 & 41.88
\end{tabular} \\
\hline & 5 & 1.03 & 5.78 & 10.26 & 16.77 & 20.46 & \begin{tabular}{|l|l|}
6 & - \\
\end{tabular} & 1.40 & 5.23 & 8.75 & 12.00 & 25.11 & 1 \\
\hline lates & Control & 26.90 & 38.83 & - & - & - & - & 23.69 & 31.13 & - & - & - & - \\
\hline & 1 & 8.41 & 15.92 & 22.95 & 44.38 & 3 & - & 7.43 & 14.32 & 26.65 & 549.70 & & \\
\hline & 3 & 9.98 & 15.92 & 22.95 & 33.77 & 742.01 & 149.17 & 10.98 & 17.07 & 24.71 & 34.49 & 941.19 & \begin{tabular}{l|l|}
9 & 48.45 \\
\end{tabular} \\
\hline & 5 & 5.01 & 11.39 & 18.70 & 26.51 & 32.69 & & 3.60 & 9.21 & 16.34 & 24.86 & 631.08 & \\
\hline L.S.D 5 & & 3.80 & 5.74 & 6.62 & 8.01 & 10.46 & \begin{tabular}{|l|l|}
6 & 6.96 \\
\end{tabular} & 6.64 & 8.63 & 8.69 & 8.06 & 9.04 & 7.23 \\
\hline
\end{tabular}

II. Effect of cold storage and packaging materials during 6 weeks storage period and their interactions on total chlorophyll content (\%) of rosemary herb:

Figure (3) shows that herbs kept at low temperatures $\left(1,3\right.$ and $\left.5^{\circ} \mathrm{C}\right)$ maintained their chlorophyll level for longer time than those kept under room temperature. It also shows that those kept at $1{ }^{\circ} \mathrm{C}$ slowed down chlorophyll degradation than at 3 or $5{ }^{\circ} \mathrm{C}$. Changes in the level of chlorophyll, during 
refrigerated storage, depended on the temperature of storage of the frozen product. The lower storage temperature contributed to a better preservation of chlorophyll, which might be attributed to more decrease in the rate of chemical and enzymatic reactions at lower storage temperature. Similar results are obtained by Lisiewska et al. (2004) on dill.
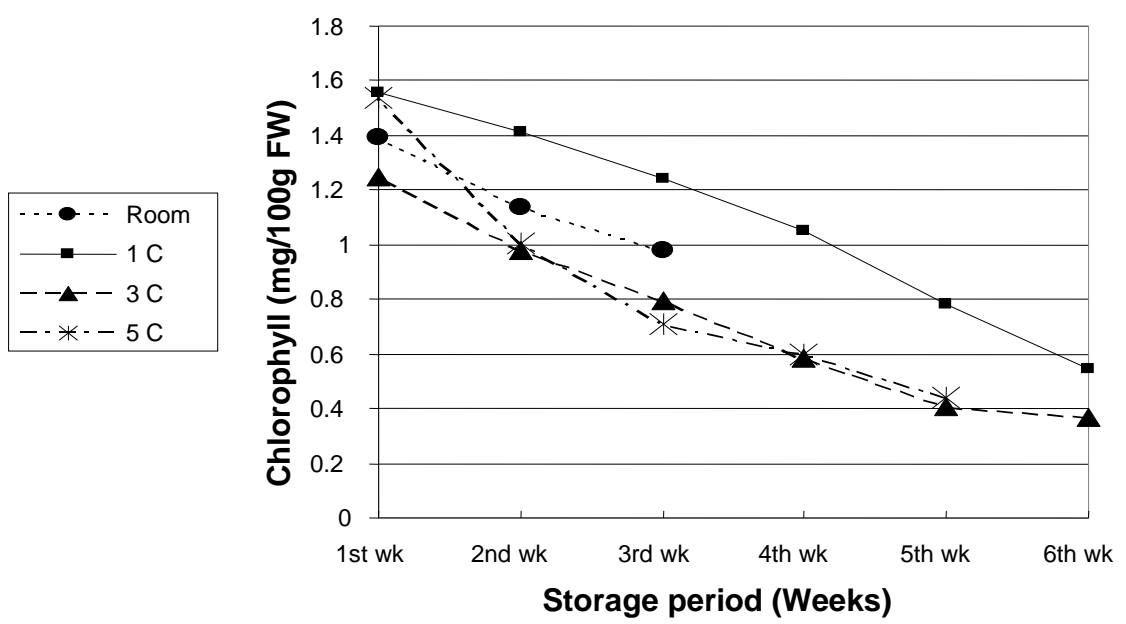

Figure (3): Total chlorophyll content (\%) of rosemary fresh herbs stored at room temperature 1,3 and $5^{\circ} \mathrm{C}$ throughout their storage period (Mean of both summer seasons 2006 and 2007).

Figure (4) shows that the chlorophyll content of rosemary was decreased with increasing the storage period. After three weeks of storage, herbs kept in Butter bags (P1) and Foam plates covered with plastic film (P9) had lower chlorophyll content than other packages. At the end of the storage period (after six weeks), herbs kept in Aluminum foils (P5) had the highest chlorophyll content. The other treatments gave same trend during different storage periods. Lopez-Ayerva et al. (1997) mentioned that if the acceptability of the product was limited by a $20 \%$ loss of chlorophyll content, the frozen product of leaves or whole plants of dill, could be stored for 12 months because low temperature keeps the chlorophyll content below that level. 


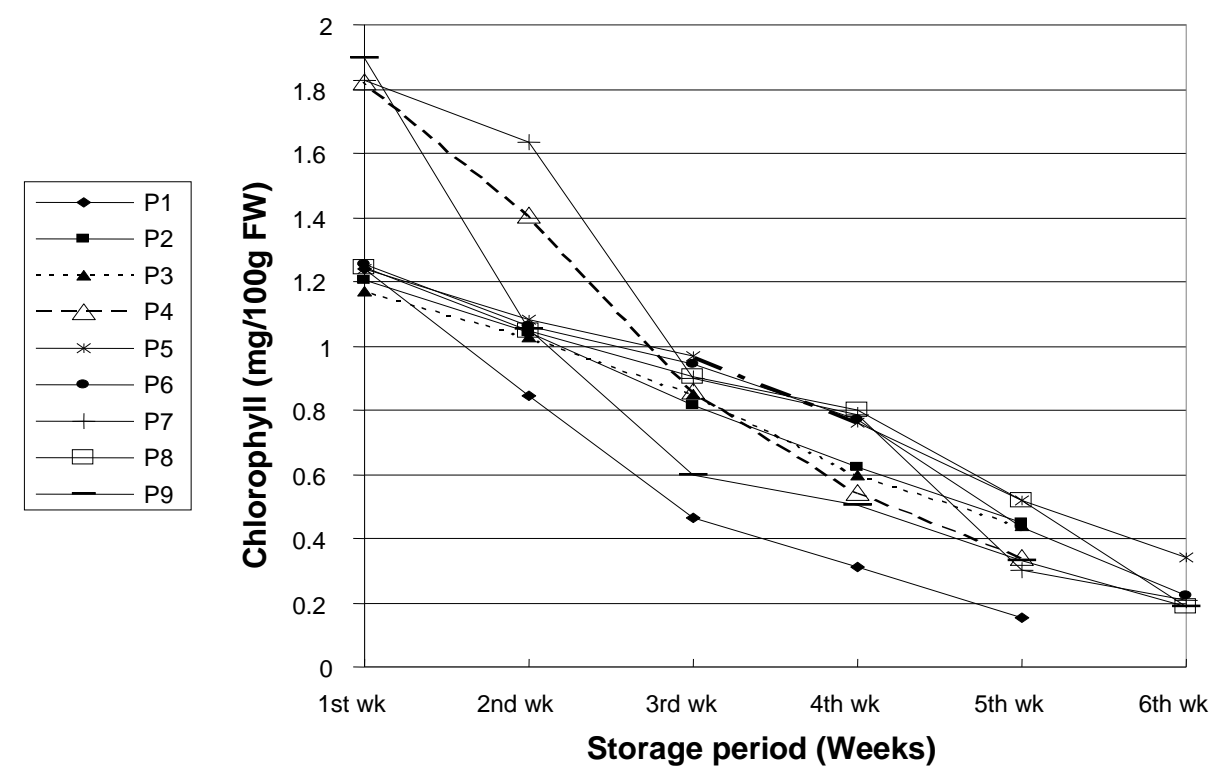

Figure (4): Total chlorophyll content (\%) of rosemary fresh herbs stored in different packaging materials ${ }^{*}$ throughout their storage period (Mean of both summer seasons 2006 and 2007).

* Butter bags (P1)

Polyethylene bags (P4)

Cellophane bags (P2)

Nylon bags (P3)

Aluminum plates covered with foil (P6) Aluminum foils (P5)

Foam plates covered with foil (P8)

Aluminum plates covered with plastic film (P7) Foam plates covered with plastic film (P9)

Data in Table (2) show also that the increase of storage period decreased the total chlorophyll content which may be attributed to some degradation in plant with increasing the storage periods. It is also obvious that most packages maintained the chlorophyll content of the herb for longer period when stored at lower temperature $\left(1^{\circ} \mathrm{C}\right.$ or $\left.3^{\circ} \mathrm{C}\right)$. It is also clear that Aluminum foils (P5), Aluminum plates covered with foil (P6), Aluminum plates covered with plastic film (P7), Foam plates covered with foil (P8), and Foam plates covered with plastic film (P9) kept the chlorophyll content of the herb at high values for long period especially at $1^{\circ} \mathrm{C}$.

These results agree with Loaiza and Cantwell, (1997) and Lange, (2000) who mentioned that the total chlorophyll content was affected by using different packaging materials under the same cooling temperature and also affected by the various cooling temperature under the same packaging materials 
Abdel-Kader, H.H. et al.

Table (2): Total Chlorophyll (\%) of rosemary fresh herb as affected by different packing materials and storage temperature (room, 1,3 and $5{ }^{\circ} \mathrm{C}$ ) and their interactions during 6 weeks period in the first and second summer seasons (2006 \& 2007).

\begin{tabular}{|c|c|c|c|c|c|c|c|c|c|c|c|c|c|}
\hline \multirow{3}{*}{$\begin{array}{c}\text { Packaging } \\
\text { materials }\end{array}$} & \multirow{3}{*}{$\begin{array}{l}\text { Storage } \\
\text { Temp. } \\
{ }^{\circ} \mathrm{C}\end{array}$} & \multicolumn{12}{|c|}{ Storage period (weeks) } \\
\hline & & \multicolumn{6}{|c|}{$1^{\text {st }}$ season } & \multicolumn{6}{|c|}{$2^{\text {nd }}$ season } \\
\hline & & 1 & 2 & 3 & 4 & 5 & 6 & 1 & 2 & 3 & 4 & 5 & 6 \\
\hline \multirow{4}{*}{$\begin{array}{l}\text { Butter bags } \\
\text { (P1) }\end{array}$} & Control & 1.45 & 0.84 & - & - & - & - & 1.49 & 0.89 & - & - & - & - \\
\hline & 1 & 1.33 & 1.14 & 1.04 & 0.70 & 0.59 & - & 1.37 & 1.19 & 1.07 & 0.73 & 0.62 & - \\
\hline & 3 & 1.00 & 0.89 & 0.77 & 0.50 & - & - & 1.05 & 0.92 & 0.79 & 0.52 & - & - \\
\hline & 5 & 1.06 & 0.40 & - & - & - & - & 1.09 & 0.43 & - & - & - & - \\
\hline \multirow{4}{*}{$\begin{array}{c}\text { Cellophane } \\
\text { bags } \\
\text { (P2) }\end{array}$} & Control & 1.31 & 1.19 & 0.94 & - & - & - & 1.35 & 1.22 & 0.95 & - & - & - \\
\hline & 1 & 1.24 & 1.18 & 1.03 & 0.92 & 0.50 & - & 1.26 & 1.20 & 1.06 & 0.96 & 0.52 & - \\
\hline & 3 & 1.36 & \begin{tabular}{|l|}
1.09 \\
\end{tabular} & 0.85 & \begin{tabular}{|l|}
0.57 \\
\end{tabular} & 0.35 & - & 1.38 & \begin{tabular}{|l|}
1.10 \\
\end{tabular} & 0.87 & 0.59 & 0.37 & - \\
\hline & 5 & 0.83 & \begin{tabular}{|l|}
0.64 \\
\end{tabular} & 0.35 & 0.31 & 0.25 & - & 0.86 & 0.68 & 0.38 & 0.34 & 0.28 & - \\
\hline \multirow{4}{*}{$\begin{array}{c}\text { Nylon bags } \\
\text { (P3) }\end{array}$} & Control & 1.31 & 1.19 & 0.94 & - & - & - & 1.41 & 1.17 & 0.96 & - & - & - \\
\hline & 1 & 1.44 & 1.30 & 1.21 & \begin{tabular}{|l|}
1.02 \\
\end{tabular} & 0.53 & - & 1.47 & 1.32 & 1.25 & 1.06 & 0.57 & - \\
\hline & 3 & 0.74 & 0.68 & 0.54 & 0.40 & 0.20 & - & 0.75 & 0.70 & 0.56 & 0.41 & 0.22 & - \\
\hline & 5 & 1.14 & 0.89 & 0.63 & 0.49 & 0.23 & - & 1.16 & 0.90 & 0.65 & 0.51 & 0.26 & - \\
\hline \multirow{4}{*}{$\begin{array}{l}\text { Polyethylene } \\
\text { bags } \\
\text { (P4) }\end{array}$} & Control & 1.31 & \begin{tabular}{|l|}
1.19 \\
\end{tabular} & 0.94 & - & - & - & 1.52 & \begin{tabular}{|l|}
1.29 \\
\end{tabular} & 1.20 & - & - & - \\
\hline & \begin{tabular}{|l|}
1 \\
\end{tabular} & 1.41 & \begin{tabular}{|l|}
1.35 \\
\end{tabular} & \begin{tabular}{|l|}
1.21 \\
\end{tabular} & 1.05 & 0.54 & - & 1.45 & \begin{tabular}{|l|}
1.38 \\
\end{tabular} & 1.24 & 1.10 & 0.58 & - \\
\hline & 3 & 1.75 & \begin{tabular}{|l|}
0.62 \\
\end{tabular} & 0.54 & 0.51 & 0.27 & - & 1.77 & \begin{tabular}{|l|}
0.64 \\
\end{tabular} & 0.56 & 0.54 & 0.29 & - \\
\hline & 5 & \begin{tabular}{|l|}
2.72 \\
\end{tabular} & 2.40 & 0.68 & 0.51 & 0.48 & - & 2.75 & 2.42 & 0.70 & 0.54 & 0.50 & - \\
\hline \multirow{4}{*}{$\begin{array}{l}\text { Aluminum } \\
\text { foils } \\
\text { (P5) }\end{array}$} & Control & 1.41 & 1.21 & 1.11 & - & - & - & 1.44 & 1.23 & 1.10 & - & - & - \\
\hline & 1 & \begin{tabular}{|l|}
1.53 \\
\end{tabular} & 1.31 & 1.19 & 1.18 & 1.00 & 0.80 & 1.55 & 1.35 & 1.23 & 1.20 & 1.02 & 0.82 \\
\hline & 3 & 1.10 & 1.02 & 0.83 & 0.69 & 0.52 & 0.51 & 1.12 & 1.05 & 0.84 & 0.71 & 0.62 & 0.54 \\
\hline & 5 & 0.84 & \begin{tabular}{|l|}
0.69 \\
\end{tabular} & 0.68 & 0.56 & 0.41 & - & 0.88 & 0.71 & 0.70 & 0.59 & 0.43 & - \\
\hline \multirow{4}{*}{$\begin{array}{c}\text { Aluminum } \\
\text { plates } \\
\text { covered } \\
\text { with foil (P6) }\end{array}$} & Control & 1.45 & 1.17 & 1.03 & - & - & - & 1.47 & 1.17 & 1.04 & - & - & - \\
\hline & 1 & 1.41 & 1.38 & 1.16 & 1.04 & 0.81 & 0.44 & 1.45 & 1.40 & 1.18 & 1.07 & 0.84 & 0.47 \\
\hline & 3 & 1.25 & 0.89 & 0.85 & 0.51 & 0.45 & 0.40 & 1.27 & 0.90 & 0.87 & 0.53 & 0.48 & 0.41 \\
\hline & 5 & 0.81 & 0.75 & 0.68 & 0.48 & 0.40 & - & 0.84 & 0.77 & 0.70 & 0.50 & 0.42 & - \\
\hline \multirow{4}{*}{$\begin{array}{l}\text { Aluminum } \\
\text { plates } \\
\text { covered } \\
\text { with plastic } \\
\text { film (P7) }\end{array}$} & Control & 1.44 & \begin{tabular}{|l|}
1.33 \\
\end{tabular} & - & - & - & - & 1.46 & 1.35 & - & - & - & - \\
\hline & 1 & 2.30 & 2.22 & 1.73 & \begin{tabular}{|l|}
1.33 \\
\end{tabular} & 1.07 & 0.45 & 2.35 & 2.26 & 1.77 & 1.37 & \begin{tabular}{|l|}
1.10 \\
\end{tabular} & 0.49 \\
\hline & 3 & 1.64 & 1.40 & 1.11 & 0.80 & 0.49 & 0.31 & 1.66 & 1.43 & 1.15 & 0.83 & 0.52 & 0.34 \\
\hline & 5 & 1.83 & 1.48 & 1.07 & 0.92 & 0.39 & - & 1.86 & 1.51 & 1.11 & 0.95 & 0.42 & - \\
\hline \multirow{4}{*}{$\begin{array}{l}\text { Foam plates } \\
\text { covered } \\
\text { with foil } \\
\text { (P8) }\end{array}$} & Control & 1.61 & \begin{tabular}{|l|}
1.09 \\
\end{tabular} & 0.92 & - & - & - & 1.63 & 1.08 & 0.92 & - & 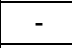 & - \\
\hline & \begin{tabular}{|l|}
1 \\
\end{tabular} & 1.34 & 1.22 & 1.07 & 1.00 & 0.98 & 0.49 & 1.38 & 1.26 & 1.11 & 1.02 & 1.01 & 0.54 \\
\hline & 3 & 0.99 & 0.93 & 0.81 & 0.64 & 0.39 & 0.19 & 1.00 & 0.95 & 0.83 & 0.67 & 0.41 & 0.21 \\
\hline & 5 & 0.95 & 0.86 & 0.73 & 0.71 & 0.62 & - & 0.98 & 0.89 & 0.76 & 0.73 & 0.65 & - \\
\hline \multirow{4}{*}{$\begin{array}{c}\text { Foam plates } \\
\text { covered with } \\
\text { plastic film } \\
\text { (P9) }\end{array}$} & Control & 1.26 & \begin{tabular}{|l|}
1.01 \\
\end{tabular} & - & \begin{tabular}{|l|}
- \\
\end{tabular} & - & - & 1.27 & \begin{tabular}{|l|}
1.03 \\
\end{tabular} & - & - & $\begin{array}{l}- \\
\end{array}$ & - \\
\hline & \begin{tabular}{|l|}
1 \\
\end{tabular} & 1.69 & 1.30 & 1.23 & 0.90 & 0.72 & 0.40 & 1.73 & 1.34 & 1.26 & 0.93 & 0.76 & 0.42 \\
\hline & 3 & 1.18 & \begin{tabular}{|l|}
1.08 \\
\end{tabular} & 0.69 & 0.43 & 0.34 & 0.31 & 1.21 & 1.11 & 0.71 & 0.45 & 0.37 & 0.34 \\
\hline & 5 & 3.30 & 0.72 & 0.62 & 0.59 & 0.50 & - & 3.39 & 0.75 & 0.67 & 0.63 & 0.54 & - \\
\hline \multicolumn{2}{|l|}{ L.S.D $5 \%$} & 0.13 & 0.24 & 0.26 & 0.23 & 0.19 & 0.15 & 0.34 & 0.36 & 0.33 & 0.36 & 0.29 & 0.18 \\
\hline
\end{tabular}




\section{Effect of cold storage and packaging materials and their interactions on the shelf-life of rosemary herb:}

Figure (5) shows the effect of storage temperature on the shelf-life of freshly packaged rosemary herbs regardless of the packaging material. It is clear that the lower the storage temperature, the longer the shelf-life in both seasons. The three storage temperatures varied slightly among each other's but significantly with room temperature, with favor to the lower cold temperature. Previous results on weight loss and changes in chlorophyll content support these results. Cold temperature would reduce respiration and transpiration of the packaged herbs, and thus delay senescence of the herb leading to increasing shelf-life. These results agree with Cantwell (1996) who reported that the optimum post harvest temperature for fresh thyme, oregano, rosemary, mints, sage, parsley, cilantro, savory, marjoram, dill, and tarragon is $0{ }^{\circ} \mathrm{C}$ and that a shelf-life from 3 to 4 weeks can be achieved at this temperature, and added that expected shelf-life is 3 weeks at $0{ }^{\circ} \mathrm{C}$ and 2 weeks at $5^{\circ} \mathrm{C}$. Same conclusions were previously reported by Joyce and Reid (1986).

$\square 1^{\text {st }}$ season

$2^{\text {nd }}$ season

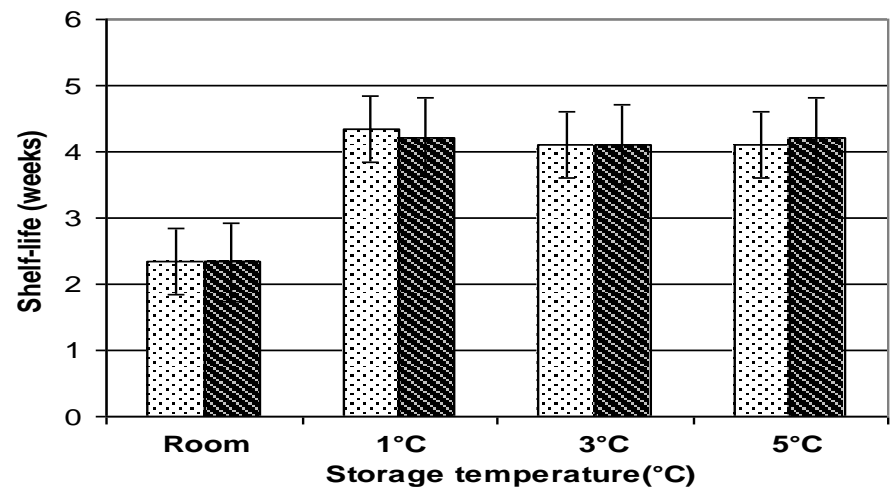

Figure (5): Mean of shelf-life of herbs stored at room temp, 1, 3 and $5^{\circ} \mathrm{C}$ during the two summer seasons (2006 \& 2007).

Figure (6) shows the effect of packaging material on the shelf life of freshly packaged rosemary herbs regardless of the storage temperature. The figure shows that the worst package was Butter bags (P1) in both seasons. It is also clear from the figure that Aluminum foils (P5), Aluminum plates covered with foil (P6), and Foam plates covered with foil (P8) had longer shelf life than other packaging materials. These three packages share the fact that they are all covered with aluminum foil. In addition to previous results on weight loss and chlorophyll content of herbs kept in these packages, aluminum foils would act as barrier against the migration of moisture, oxygen and other gases, and volatile aroma, as well as against the impact of light is generally higher than any plastic laminate material. Since Different types of packaging material would have different permeability and gas exchange ability, Aluminum foil seems to improve the shelf life through creating a modified atmosphere inside the package that would lead to delaying senescence of the herb. These results are in accordance with these of Aharoni et al. (1989) on dill and coriander, Gomez et al. (1999) on coriander, 
Rashed (2002) on dill, coriander and parsley and Al-Kershi (2003) on spearmint and sweet basil.

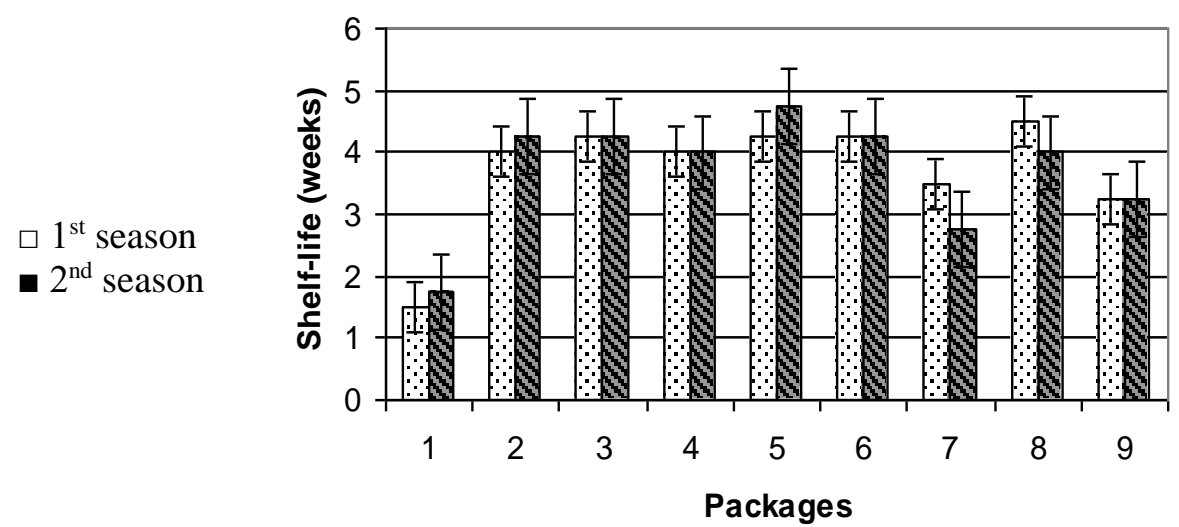

Figure (6): Mean of shelf-life of herbs stored in different packaging materials during the two summer seasons (2006 \& 2007).

* Butter bags (P1)

Polyethylene bags (P4)

Cellophane bags (P2) Aluminum foils (P5)

Aluminum plates covered with foil (P6) Aluminum plates covered with plastic film (P7)

Foam plates covered with foil (P8)

Foam plates covered with plastic film (P9)

Table (3) shows the effects of the interaction between storage temperature and different packaging materials on the shelf- life of rosemary. Data show that shortest shelf- life for each packaging material was when this package was stored at room temperature compared with other temperatures in both seasons, while longest shelf- life was dependent on temperature and type of package. Shortest shelf- life was in case of Butter bags (P1) and Aluminum plates covered with plastic film (P7) stored at room temperature, while the longest were in case of Aluminum foils (P5) and Aluminum plates covered with foil (P6) stored for up to six weeks at $3{ }^{\circ} \mathrm{C}$ in both seasons. These results are similar to Cantwell and Reid (1993), and Rogers and Fischetti (1994), who reported that the best post harvest conditions for preservation of fresh rosemary herb include storage at low temperature with using different packing materials, and under this condition, a shelf-life of 6 weeks can be expected.

The longest shelf- life for Foam plates covered with plastic film (P9) significantly indifferent at all the three cold storage temperature, while the longest shelf-life of Cellophane bags (P2), Nylon bags (P3), and Polyethylene bags (P4) at either $1^{\circ} \mathrm{C}$ or $5^{\circ} \mathrm{C}$.

These results show that although lower temperature suited most packages, the shelf- life was mainly dependent on the type of package and its response to low temperature storage. Shelf- life was not merely evaluated by weight loss and change in chlorophyll, but with other visual factors as well.

In this concern, Tucker and Maciarello (1993), reported that quality characteristics are largely visual and include appearance of freshness, uniformity of size, form and color, lack of defects (damaged or yellowed leaves, decay, insect damage, wilting). By extending the storage period under 
a certain temperature, the color of the herb in some replicates in some packages turned to black, aged, or showed growth of fungus on the herb, and thus its shelf life was terminated. In addition, chlorophyll degradation in some cases was not fast enough to terminate the shelf- life of the herb.

Table (3): Shelf-life (weeks) of rosemary fresh herbs as affected by the interaction between packaging materials and storage temperature during the two summer seasons (2006 \& 2007)

\begin{tabular}{|c|c|c|c|c|c|c|c|c|}
\hline \multirow{4}{*}{ Packaging materials } & \multicolumn{8}{|c|}{ Shelf-life (weeks) } \\
\hline & \multicolumn{8}{|c|}{ Storage temperature ${ }^{\circ} \mathbf{C}$} \\
\hline & \multicolumn{4}{|c|}{$1^{\text {st }}$ season } & \multicolumn{4}{|c|}{$2^{\text {nd }}$ season } \\
\hline & Room & $1^{\circ} \mathrm{C}$ & $3^{\circ} \mathrm{C}$ & $5^{\circ} \mathrm{C}$ & Room & $1^{\circ} \mathrm{C}$ & $3^{\circ} \mathrm{C}$ & $5^{\circ} \mathrm{C}$ \\
\hline Butter bags (P1) & 1 & 2 & 2 & 2 & 1 & 2 & 1 & 2 \\
\hline Cellophane bags (P2) & 3 & 5 & 4 & 5 & 3 & 5 & 3 & 5 \\
\hline Nylon bags (P3) & 3 & 5 & 4 & 5 & 3 & 5 & 4 & 5 \\
\hline Polyethylene bags (P4) & 3 & 5 & 3 & 5 & 3 & 5 & 3 & 5 \\
\hline Aluminum foils (P5) & 3 & 5 & 6 & 5 & 3 & 5 & 6 & 3 \\
\hline Aluminum plates covered with foil (P6) & 3 & 4 & 6 & 4 & 3 & 4 & 6 & 4 \\
\hline Aluminum plates covered with plastic film (P7) & 1 & 3 & 4 & 3 & 1 & 4 & 5 & 4 \\
\hline Foam plates covered with foil (P8) & 2 & 5 & 5 & 5 & 2 & 5 & 6 & 5 \\
\hline Foam plates covered with plastic film (P9) & 2 & 4 & 3 & 4 & 2 & 4 & 3 & 4 \\
\hline LSD 5\% & \multicolumn{4}{|c|}{0.98} & \multicolumn{4}{|c|}{1.08} \\
\hline
\end{tabular}

Summing up all factors, one can conclude that herbs packaged in Aluminum foils (P5) and Aluminum plates covered with foil (P6) stored at $3{ }^{\circ} \mathrm{C}$ maintained their fresh weight, chlorophyll content, and achieved longer shelf life than other treatments in both seasons. These results are similar to those of Lamberti and Escher (2007) as it acts as barrier against the migration of moisture, oxygen and other gases.

\section{REFERENCES}

Aharoni, N; A. Reuveni and O. Dvir (1989). Modified atmospheres in film packages delay senescence and decay of fresh herbs. Acta Hort.258: 255-260.

Aharoni, N.; O. Dvir; D. Chalupowicz and Z. Aharon (1993). Coping with postharvest physiology of fresh culinary herbs, Acta Hort: 344: 69-78.

Al-Kershi, A. G. (2003). Postharvest packaging and temperature controlled storage of spearmint and sweet basil herbs destined for medicinal and aromatic uses. Ph. D. Thesis. Fac. Agric., Alex. Univ., Egypt.

Bhide, M. (2006). Buying, using and storing their favorite spices and herbs, Cookbook, ISBN:0-9640514-1-9, Kathy Casey.

Cantwell, M. (1992). Handling of Fresh Culinary Herbs. Postharvest specialist,Small Farm News. California Univ. http:// www. Postharvest.

Cantwell, M. (1996). Herbs (Fresh Culinary), Recommendations for Maintaining Postharvest Quality. Postharvest Technology, Vegetable crops, CA. 95616

Cantwell, M.I. and M.S. Reid (1993). Postharvest physiology and handling of fresh culinary herbs. J. Herbs, Spices and Medicinal Plants.1(3):93-127 
Gomez, E.; M. Gurero and B. Bracho (1999). Postharvest performance of coriander (Coriandrum sativum L.) under refrigeration. Revista de Agronomia, Universidad delzulia 146-150. (Hort. Abst., 70 (4):3514).

Gomez, K. A. and A. A. Gomez (1984). Statistical procedures, Res. $2^{\text {nd }}$ Ed. John Wiley and Sons, Inc., New York, USA.

Herbert, D.; P.T. Phipps and R.E. Strange (1971). Determination of total carbohydrates. Methods in Microbiology, S(B): 290-341.

Joyce, D. and M. Reid (1986). Post harvest handling of fresh culinary herbs. The Herb, Spice, and Medicinal Plant Digest. 4(2): 1-7.

Karwowska, K. (1997). Influence of storage methods of fresh basil (Ocimum basilicum L.) and tarragon (Artemisia dracunculus L.) on their quality. J. Hort. Sci., 18: 127-139.

Keville, K. (1999). Herbs "An Illustrated Encyclopedia" Michael Friedman Publishing Group Inc. p. 167-168.

Kmiecik, W.; Z. Lisiewska and G. Jaworska (2001). Effect of storage conditions on the technological value of dill (Anethum graveolens L.). Folia Hort. 13(1): 33-43.

Kowalchik, C. and Rodale's, W. H. (1998): Illustrated Encylopedia of Herbs, Rodale Press, P. 428-432.

Kwon-HyeJeong; Hong-GeoPyo; Kong-YoungJun; Kwon-HJ; Hong-GP and Kong-YJ (1998). Effect of precooling packing on shelf life in celery. RDA- Journal of Horticulture Science. 40:2, 37-43.

Lamberti, M. and F. Escher (2007). Aluminium foil as a food packaging material in comparison with other materials, Food Reviews international, Vol.23(4): 407- 433.

Lange, D. L. (2000). New film technologies for horticultural products. Horticulturae Technology 10: 486-490.

Lisiewska, Z.; W. Kmiecik and J. Supski (2004). Effect of usable part and pretreatment on the content of chlorophylls and carotenoids in frozen dill (Anethum graveolens L.), depending on the time and temperature of storage. Food Chemistry. 84(4): 511-518.

Loaiza, J. and M. Cantwell (1997). Postharvest physiology and quality of cilantro (Coriandrum sativum L.). Horticulturae Science. 32: 104-107.

Lopez Ayerva, G.; G. Peiser; X. L. Nie and M. Cantwell (1997). Quality changes in packaged salad products during storage. Zeitschrift fur Lebensmittel Untersuchung Forschung. 205: 64-72.

Rashed, Nahed, M.M. (2002). Effect of fertilization on the growth and storability of some aromatic plants. M.Sc. Thesis, Fac. Agric., Kafr ELSheikh, Tanta Univ.

Rogers, J. and F. Fischetti (1994). Flavors and Spices. In Kirk-Othmer Encyclopedia of Chemical Technology; Kroschwitz, J. I., Howe- Grant, M. Eds.; Wiley: New York, USA. p. $16-61$.

Sankat, C.K.; V. Maharaj and B. Lauckner (1994). The effect of temperature and packaging on the storage of dasheen (Colocasia esculenta) leaves. ASEAN. Food J., 10(1): 3-9.

Tomkins, B. and A. Chennell (2000). Storing and Handling Culinary Herbs. Short Report No.69. Horticultural Development, (public, No.99/142, DAV-103A). 
Wilson, L.; M. Boyette and E. Estes (1995). Posthavest Handling and Cooling of Fresh Fruits, Vegetables and Flowers for Small Farms. Leaflets 800804. North Carolina Cooperative Extension Service. p.17. Accessed on-line at: http:// www.foodsafety.org/nc/nc1055.htm

Yamauchi, N. and A. E. Watada (1991). Regulated Chlorophyll degradation in spinach leaves during storage. J. Amer. Soc. Hort. Sci. 16(1): 58-62.

تأثير التخزين البارد وعبوات التخزين المختلفة على جودة عشب حصالبان الطازج:

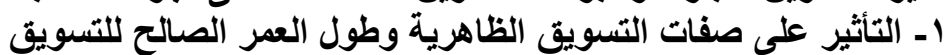

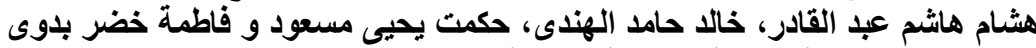

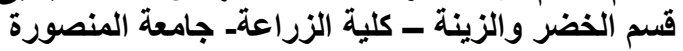

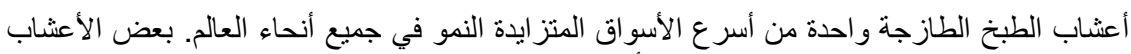

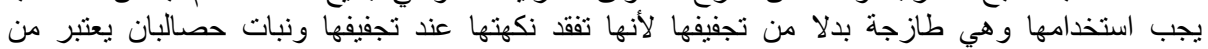
الأعشاب الطازجة الأكثر استخداما.

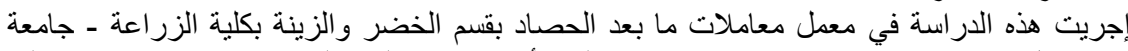

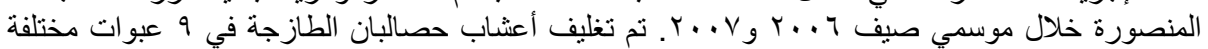

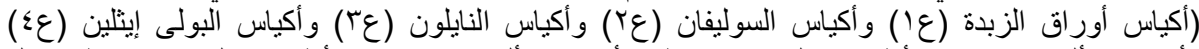

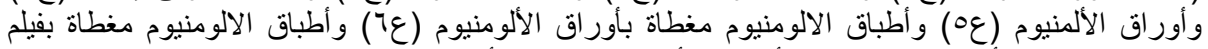

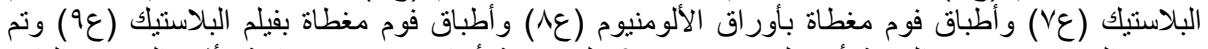

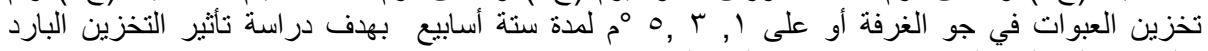

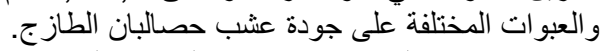

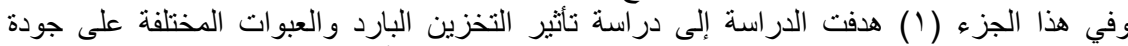

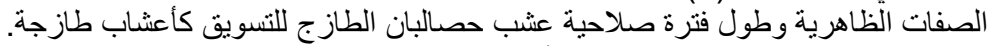
ويمكن تلخيص النتائج المتحصل علئها في التنالي:-

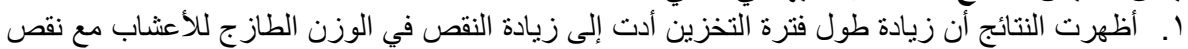

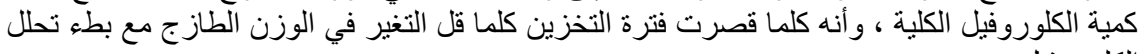

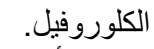

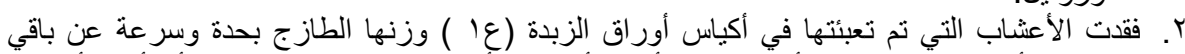

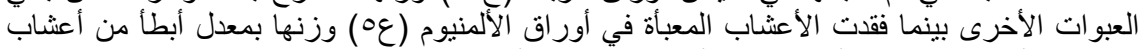

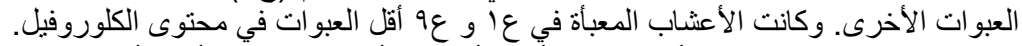

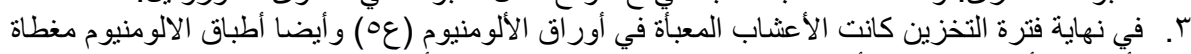

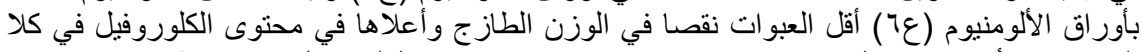

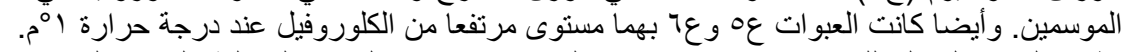

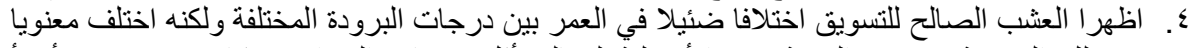

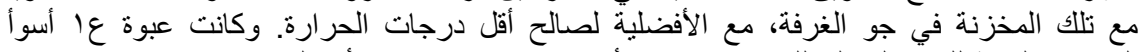

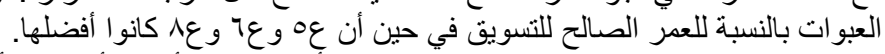

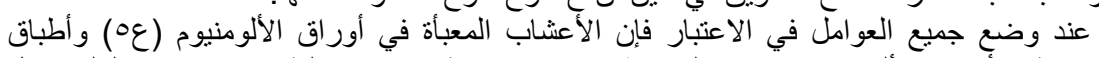

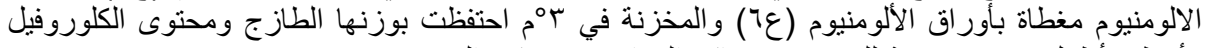
وأعطت أطول عمر صلاحية للتسويق عن باقي المعاملات في كلا الموسمين.

كلية الزراعة - جامعة المنصورة كلية الزراعة - جامعة الأسكندرية

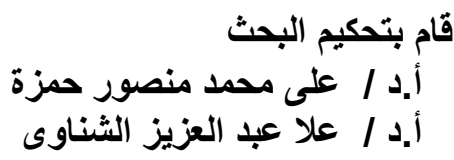

